no widely accepted hypothesis consistent with all the facts known about crossing-over in higher forms has yet been proposed. Perhaps one of the most ingenious of the earlier suggestions, especially in the light of the recent proposal of Watson and Crick as to how macromolecules of deoxyribonucleic acid might reproduce, was the one presented by the late John Belling.

In recent years a marked revival of interest in the crossing-over approach has been stimulated by a series of inter-related developments in genetics. Among these is the large body of evidence that pneumococcal transforming principles are deoxyribonucleic acid, the demonstration that genetic information in bacterial viruses is transmitted in the form of this macromolecule, and the realization that the Watson-Crick double helix structure of deoxynucleic acid might well explain how genetic information is replicated.

A symposium on "Genetic Recombination" was held in the United States during April 19-21, 1954, at the Oak Ridge National Laboratory, and this volume consists of sixteen papers summarizing what had been accomplished at the time of that meeting. The subjects dealt with include pneumococcal transformations, transduction and other recombination mechanisms in bacteria; crossing-over in fungi, algæ, higher plants and higher animals ; and, finally, the oxygen effect on chromosome aberrations in higher forms. The symposium dealt with, but did not finally answer, the important question of whether the recombination mechanisms in bacterial viruses and higher plants and animals are fundamentally the same. Chromosomes of the latter contain protein as well as deoxyribonucleic acid and are many orders of magnitude larger than the deoxyribonucleic acid helices of viruses. In addition, in a number of higher forms it is known that, in contrast to recombination in bacterial viruses, a single cross-over produces complementary recombination structures. It may therefore be too much to hope that a single mechanism will account for both processos.

Progress in understanding genetic recombination is at present being made so rapidly and requires so much specialized knowledge for its full appreciation that it is difficult for the general geneticist or biologist to keep up to date. Reports of symposia such as the Oak Ridge one are a great help in this respect.

G. W. BEADLF

\section{THE NATIONAL GALLERY, LONDON}

\section{The National Gallery 1938-54}

Pp. 124+20 plates. (London: National Gallery, 1955.) 12s. $6 d$. net.

$\Gamma^{N}$ 1938 the National Gallery, presumably for reasons of economy, ceased to publish a Director's innual report. That practice is now to start again and, in the meantime, the Trustees have issued a most welcome comprehensive survey of the years 1938-54. This is a model of lucid statement. It not only gives a detailed account of those things one expects to hear about-the evacuation of the collection to Manod quarry at the beginning of the Second World War, the acquisitions during the period under review, and the development of a Scientific Department and a Conservation Depart. ment-but, in addition, it records activities which annual reports usually take for granted. It explains, for example, the duties of the senior members of the staff-the keepers and assistant keepers-and gives the public some insight into the extraordinarily complicated work involved in compiling catalogues of the standard of those already produced by Mr. Martin Davies and Mr. Neil MacLaren. Before the War a catalogue of the whole collection was available, but the information it contained was too slight to be of very much use to scholars. The detailed catalogues of the British, French, Spanish, Early Netherlandish and Earlier Italian Schools issued during and after the War have, however, set a standard of scholarship which is a model to the galleries of the world. A new general catalogue, which, one hopes, will be of a more, lively character than the pre-war edition, is also in preparation.

The report is not only comprehensive, it is also honest. It records in detail the treatment given to every picture that has been restored and cleaned since the Conservation Department was set up in 1947, and reveals the extent to which scientific examination can solve problems which the eye alone can only guess at. The cleaning of Piero della Francesca's "Nativity" has, for example, shown quite certainly that the thin condition of parts of this picture is due not to its being unfinished, as has often been suggested, but to drastic overcleaning in the past. Again, examination of Van Dyck's "Charles I on Horseback" showed that, when it was first relined, the canvas had been cut in two because of its great size. The work of removing previous relinings and restoring the original canvas involved the construction of a special table and the placing of an awning over the studio roof which had not been repaired since the War.

The question of war damage and its repair is one of the two disquieting subjects in the report, the other being the more serious one of lack of funds. Bomb damage put the west wing of the building out of action, and it was decided to instal as soon as possible a badly needed air-conditioning plant which would serve the rooms in this wing as they were re-opened. The plant was installed after delay, and the rooms are gradually coming into use; but even by the end of 1956, eleven years after the end of the War, parts of this block of the gallery will still not be available for the exhibition of pictures. This is the more serious when one realizes that since 1938 the collection has been increased by about a hundred and eighty pictures. A number of these have been transferred to the Tate Gallery, but there have also been transfers to the National Gallery from the Tate. Rebuilding does, however, progress, if only slowly. The problem of the lack of funds available for purchases is more urgent. A national collection, however large, is never complete. There will always be certain pictures which, if they come on the market, should be bought for the National Gallery rather than any other. But the annual government grant to-day, $£ 10,500$, stands only a few hundreds higher than it did in 1880. The Gallery has an additional income of about $£ 10,000$ from endowments, but with only $£ 20,000$ a year available, it is quite unable to compete for masterpieces unless Parliament votes a special grant-in-aid. The need for a very much larger annual grant is undeniable.

This report is not written for the profession only. It is written for all those persons who care for fine pictures, and it should be read by them. It can be strongly recommended.
K. J. GARLICK 